\title{
Synergistic effects between omnivorous filter-feeding fish and nutrient enrichment on algal biomass
}

\author{
Efeitos sinérgicos entre peixes onívoros filtradores e enriquecimento por nutrientes \\ sobre a biomassa de algas
}

\section{Leonardo Henrique Teixeira ${ }^{1}$ and José Luiz Attayde ${ }^{1}$}

\author{
${ }^{1}$ Departamento de Ecologia, Universidade Federal do Rio Grande do Norte - UFRN, \\ CEP 59072-970, Lagoa Nova, Natal, RN, Brazil \\ e-mail: leonardo.htp@gmail.com; attayde@cb.ufrn.br
}

\begin{abstract}
Aim: The Nile tilapia - Oreochromis niloticus (Linnaeus 1758) - is an exotic omnivorous filter-feeding fish that has been stocked for three decades in man-made lakes of Northeastern Brazil. Most experiments manipulating omnivorous filter-feeding fish in eutrophic lakes and reservoirs shows that their presence tends to increase phytoplankton biomass and primary production. In this study, we tested the hypothesis that tilapia interact synergistically with nutrient enrichment so that the effects of omnivorous fish on phytoplankton biomass becomes more intense with increasing nutrient concentration. Methods: A field experiment with a $2 \times 3$ factorial design was performed during four weeks in twenty-four mesocosms $\left(0.25 \mathrm{~m}^{3}\right)$ to which six treatments were randomly allocated: fingerling addition (F), juvenile tilapia addition (J), nutrient addition (NP), nutrient and fingerling addition (NPF), nutrient and juvenile tilapia addition (NPJ) and a control treatment with no tilapia or nutrients addition (C). A two-way repeated measures ANOVA was done to test for time (t), tilapia and nutrients effects and their interaction on total phosphorus, total nitrogen and chlorophyll- $a$ concentrations. Results: The results showed a positive effect of nutrient addition on total phosphorus, total nitrogen and chlorophyll- $a$ concentrations and a positive effect of tilapia on the concentration of chlorophyll- $a$. As expected, we found a synergistic interaction between the positive effect of Nile tilapia and nutrient enrichment on phytoplankton biomass. Conclusions: The above results suggest that controlling tilapia abundance through fisheries management is a potential tool to improve water quality and mitigate the effects of lake and reservoir eutrophication.
\end{abstract}

Keywords: biomanipulation; chlorophyll- $a$; eutrophication; exotic species.

Resumo: Objetivo: A tilápia do Nilo - Oreochromis niloticus (Linnaeus 1758) - é um peixe exótico com alimentaçáo onívoro-filtradora que tem sido estocado por três décadas em lagos artificiais do Nordeste do Brasil. A maioria dos experimentos manipulando peixes onívoro-filtradores em lagos e reservatórios eutrofizados mostra que sua presença tende a aumentar a biomassa fitoplanctônica e a produção primária. Neste estudo, testou-se a hipótese de que a tilápia interage sinergicamente com o enriquecimento de nutrientes, de modo que os efeitos de peixes onívoros sobre o fitoplâncton tornam-se mais intensos com o aumento da concentraçáo de nutrientes. Métodos: Um experimento de campo com delineamento fatorial $2 \times 3$ foi realizado durante quatro semanas em 24 mesocosmos $\left(0,25 \mathrm{~m}^{3}\right)$, nos quais seis tratamentos foram aleatoriamente alocados: adição de peixes alevinos $(\mathrm{F})$, adiçãoo de tilápia juvenil (J), adição de nutrientes $(\mathrm{NP})$, adição de nutrientes e alevinos (NPA), nutrientes e tilápia juvenil (NPJ) e um tratamento controle, sem tilápias ou nutrientes (C). Uma ANOVA bifatorial com medidas repetidas foi realizada para testar os efeitos do tempo $(\mathrm{t})$, da tilápia e dos nutrientes, além da interaçáo entre tilápias e nutrientes sobre as concentraçôes de fósforo total, nitrogênio total e clorofila a. Resultados: Os resultados mostraram um efeito positivo da adição de nutrientes sobre as concentraçóes de fósforo total, nitrogênio total e clorofila; e um efeito positivo das tilápias sobre a concentração de clorofila a. Como esperado, verificou-se uma interação sinérgica entre o efeito positivo da tilápia do Nilo e do enriquecimento por nutrientes na biomassa fitoplanctônica. Conclusóes: Os resultados sugerem que o controle da abundância de tilápias, através do manejo da pesca, é uma ferramenta potencial para melhorar a qualidade da água e mitigar os efeitos da eutrofizaçáo em lagos e reservatórios.

Palavras-chave: biomanipulação; clorofila $a$; espécie exótica; eutrofização. 


\section{Introduction}

Reservoirs in the semi-arid region of the Northeastern Brazil constantly suffer with the effects of excessive inputs of nutrients from both natural and anthropogenic sources. The eutrophication of these reservoirs has favored the exotic fish Nile tilapia, Oreochromis niloticus, which has been stocked in the reservoirs since the 70's to increase yields of inland fisheries and aquaculture. The Nile tilapia is an omnivorous filter-feeding fish that can feed on phytoplankton, zooplankton and suspended detritus. So, it can reduce phytoplankton biomass directly by grazing but it can also increase phytoplankton biomass indirectly by feeding on zooplankton and reducing their grazing pressure on phytoplankton. Furthermore, fish can also enhance primary production and increase algal biomass by releasing nutrients through egestion and excretion (Attayde \& Hansson, 1999), and also by resuspending detritus from sediment. Therefore, the overall effect of omnivorous filter-feeding fish such as the Nile tilapia on phytoplankton biomass should depend on the relative importance of these direct and indirect effects.

Nile tilapia has an ontogenetic shift on feeding habits, changing from visual predation on zooplankton when fingerlings to filter-feeding on phyto- and zooplankton when juveniles (Beveridge \& Baird, 2000; Attayde \& Menezes, 2008). Therefore, the effects of the Nile tilapia on plankton communities should depend on the relative abundance of these two planktivore types (Attayde \& Menezes, 2008). Although the trophic cascading effects of planktivorous fish has been widely reported on the literature, omnivorous filter-feeding fish effects are more complex, since it can affect primary productivity and, hence, algal biomass in opposite ways (Okun et al., 2007; Attayde et al., 2010; Menezes et al., 2010).

Previous studies have attempted to elucidate how omnivorous filter-feeding fish interact with nutrient enrichment to affect phytoplankton biomass (Drenner et al., 1996, 1998; Chumchal \& Drenner, 2004). According to Drenner et al. (1996, 1998), omnivorous filter-feeding fish may interact synergistically with the trophic state of the environment. Therefore, their effects on phytoplankton biomass would become more intense with increasing nutrient concentrations. Nevertheless, recent studies have contradicted Drenner's hypothesis of synergistic interaction and the issue is still under debate (Menezes et al., 2010). In this paper, we tested the hypothesis that the stocking of Nile tilapia in the reservoirs interact synergistically with nutrient enrichment to increase phytoplankton biomass and decrease water quality. Answering this question is of more than academic interest since it is crucial for reservoir water quality management in the Northeast of Brazil, a region with scarce water resources and many conflicts between their distinct uses.

\section{Material and Methods}

\subsection{Experimental design}

The experiment was conducted between April $3^{\text {rd }}$ and May $1^{\text {st }}(2008)$ in the fish farm of Escola Agrícola de Jundiaí (EAJ), located in the municipality of Macaíba about $26 \mathrm{~km}$ from Natal, Rio Grande do Norte. Twenty-four water tanks made of fiberglass with a capacity of 250 liters $\left(0.25 \mathrm{~m}^{3}\right)$ were filled with water from the nearby reservoir and distributed linearly next to the tanks where we had collected the fishes. These mesocosms were open to the atmosphere, but closed at the bottom.

The experiment had a $2 \times 3$ factorial design where two levels of nutrients (with/without addition) were crossed with three levels of fish (no fish, fingerlings, juveniles) resulting in 6 treatments: fingerlings $(\leq 5 \mathrm{~cm})$ addition $(F)$, juveniles $(\geq 10 \mathrm{~cm})$ addition (J), nutrients addition (NP), fingerlings and nutrients addition (NPF), juveniles and nutrients addition (NPJ) and a control (C) with no fingerlings, juveniles or nutrients. The treatments with juveniles (J) were stocked only with one individual. Fingerling tilapias were added in more number so that fingerlings and juvenile treatments had similar fish biomass.

The treatments were replicated four times and randomly allocated in the 24 mesocosms, which contained the plankton community and water of the fish breeding tanks. There were no further additions of water to refill the mesocosms. The fish used in our experiment were also from the breeding tanks. Fishes were not fed with external resources, so they necessarily fed on plankton within the mesocosms. Inorganic nutrients were added weekly during the experimental period, including the first experimental day, but after adding the fishes. A volume of $100 \mathrm{ml}$ were applied for each one of the twelve treatments with nutrients addition, completing 1.2 liters of sodium nitrate $\left(\mathrm{NaNO}_{3}\right)$ and monobasic potassium phosphate $\left(\mathrm{KH}_{2} \mathrm{PO}_{4}\right)$ solutions. Sodium nitrate had a calculated concentration of $1000 \mu \mathrm{g} . \mathrm{L}^{-1}$ and monobasic potassium phosphate had a concentration of $100 \mu \mathrm{g} \cdot \mathrm{L}^{-1}$. 
The experiment lasted four weeks and samples were collected weekly since the beginning of the experiment. An initial measurement (before nutrient and fish addition) was also performed to ensure that there were no differences in the monitored variables at the beginning of the experiment. In each mesocosm the concentrations of total phosphorus, total nitrogen and chlorophyll- $a$ were monitored.

\subsection{Sampling and analysis}

Water samples were collected using a $500 \mathrm{ml}$ plastic bottle, after homogenization of the mesocosm water. Chlorophyll-a concentration were determined with a spectrophotometer at 665 and $750 \mathrm{~nm}$ wavelengths after the filtration of $150 \mathrm{ml}$ of water samples through Whatman 934-AH fiberglass filters and extraction of chlorophyll with ethanol 95\% PA for 18 hours, according to Jespersen \& Christoffersen (1987). No acidification was carried out to correct the possible influence of phaeopigments over the absorbance readings, because acidification may decrease precision and accuracy of chlorophyll-a estimates (Stich \& Brinker, 2005). For analysis of total phosphorus and total nitrogen, the oxidation of the samples was performed through the method described by Valderrama (1981). Total phosphorus and total nitrogen concentrations were determined by the ascorbic acid and sodium salicylate methods, respectively (APHA, 1997).

A repeated measures two-way ANOVA was performed to test the separate effects of fish, nutrients and their interaction on the concentrations of chlorophyll- $a$, total nitrogen and total phosphorus. The assumption of the homogeneity of variance for the repeated measures test was fulfilled. It was verified by the conditional boxplot tool (Zuur et al., 2010). The statistical analysis was performed using the software Systat 12.

\section{Results}

The mean concentrations of total phosphorus ( \pm SE) were similar at the start of the experiment (Figure 1). However, during the experiment there was a clear increase in the mean values of total phosphorus concentrations in the treatments with nutrients addition (NP, NPF and NPJ). The mean concentrations of total nitrogen $( \pm \mathrm{SE})$ were also similar at the start of the experiment, but decreased in the treatments without nutrient enrichment over the course of the experiment (Figure 2).

Results of the two-way ANOVA showed that nutrient enrichment significantly increased total phosphorus, total nitrogen and chlorophyll-a concentrations, while fish addition only increased chlorophyll-a concentration (Table 1). Results also showed a significant synergistic interaction effect between nutrients and fish on chlorophyll-a concentrations (Table 1, Figure 3).

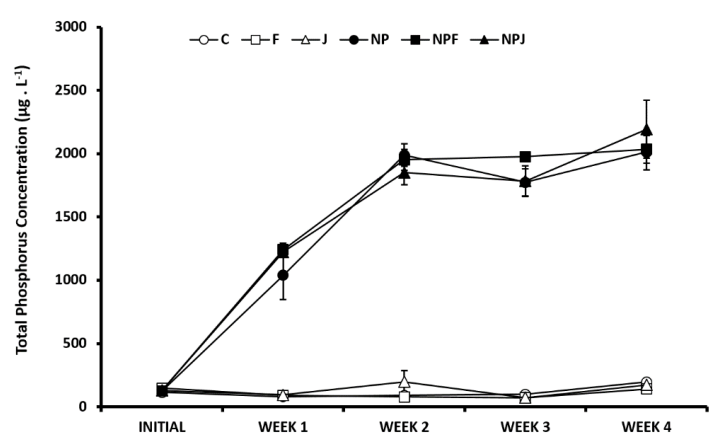

Figure 1. Medium values(+ - SE) for Total Phosphorus concentration analysis in six combinations of nutrients (NP), fingerlings (F) and juvenile (J) Nile tilapia treatments in a four-week tropical shallow lake experiment.

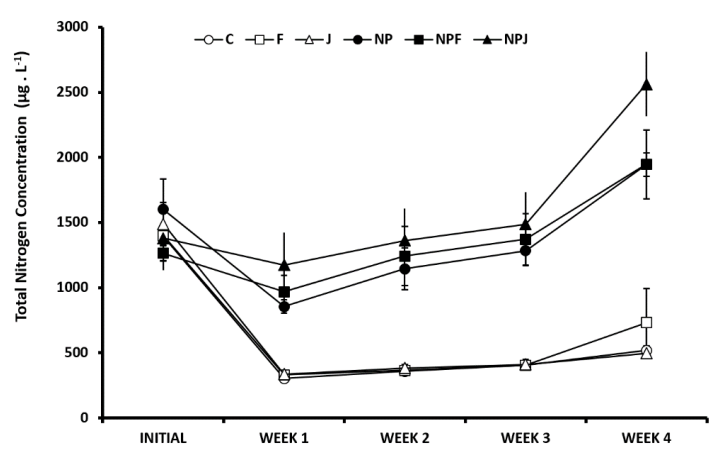

Figure 2. Medium values (+ - SE) for Total Nitrogen concentration analysis in six combinations of nutrients (NP), fingerlings (F) and juvenile (J) Nile tilapia treatments in a four-week tropical shallow lake experiment.

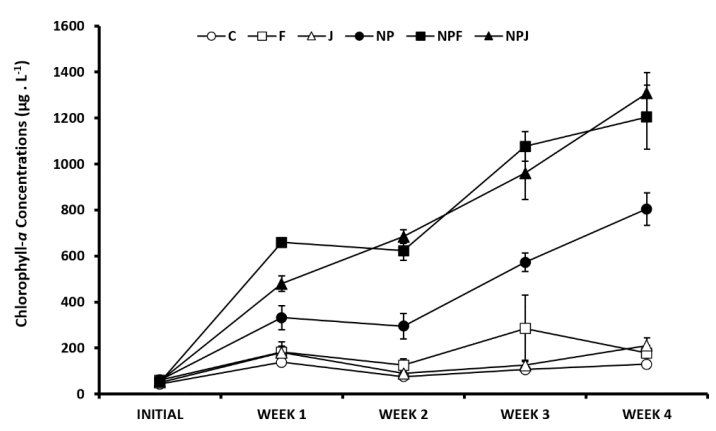

Figure 3. Medium values (+ - SE) for Chlorophyll- $a$ concentration measurements taken along the experimental period in six combinations of nutrients (NP), fingerlings (F) and juvenile (J) Nile tilapia treatments. 
Table 1. F-values of repeated measures ANOVA for Total Phosphorus, Total Nitrogen and Chlorophyll- $a$ measurements taken in all factorial combination of the following treatments: nutrients (NP), fishes (fingerlings and juvenile), and nutrients plus fishes. Mean values are represented in Figures 1, 2 and 3.

\begin{tabular}{ccccc}
\hline Variation Source & d.f. & Total Phosphorus & Total Nitrogen & Chlorophyll-a \\
\hline NUTRIENTS (NP) & 1 & $1378.45^{\star * *}$ & $189.075^{\star * *}$ & $493.001^{* * *}$ \\
FISH & 2 & 0.389 & 1.747 & $29.444^{* \star *}$ \\
NP x FISH & 2 & 0.549 & 1.723 & $14.609^{* * *}$ \\
ERROR & 18 & & & \\
TIME (T) & 4 & $183.095^{* * *}$ & $38.586^{* * *}$ & $104.26^{* * *}$ \\
T x NP & 4 & $179.575^{* * *}$ & $26.733^{* * *}$ & $65.683^{* * *}$ \\
T x FISH & 8 & 0.672 & 0.571 & $3.973^{* * *}$ \\
T x NP x FISH & 8 & 1.034 & 1.246 & $2.098^{*}$ \\
ERROR & 72 & & & \\
\hline
\end{tabular}

Significance values: ${ }^{*} \mathrm{p} \leq 0.05 .{ }^{* * *} \mathrm{p} \leq 0.001$.

\section{Discussion}

The above results confirm the hypothesis that omnivorous filter-feeding fish synergistically interact with nutrient enrichment to increase algal biomass and, therefore, the primary productivity of phytoplankton. Two mechanisms can account for such synergistic interaction. First, in the presence of fish, phytoplankton would respond more strongly to nutrient enrichment because zooplankton is controlled by fish and mortality due to zooplankton grazing is lower than in the absence of fish. Second, in the presence of omnivorous fish, nutrients accumulated in detritus would be released by fish and would stimulate further phytoplankton growth.

The first mechanism is not particular to omnivorous filter-feeding fish and can occur also in the presence of zooplanktivorous fish. However, the second mechanism can only occur if fish is able to feed on detritus and release nutrients stored in detritus back to the water, making them available again to phytoplankton. Our results suggest that the first mechanism might have accounted for the synergistic interaction observed in the experiment because there was no difference between the effects of the zooplanktivorous (F) and omnivorous (J) tilapia on phytoplankton biomass (Figure 3).

We did not analyzed fish excretion rates, so we cannot do more than speculate about nutrient remineralization by fish (Attayde \& Hansson, 1999). Therefore, the mechanism involved might have been common to both feeding strategies. Moreover, there was no significant interaction effect on total phosphorus or total nitrogen concentration making the second mechanism very unlikely (Figures 1 and 2). As a consequence of the second mechanism, total nitrogen and total phosphorus concentrations would be higher in the treatment with omnivorous juveniles than in the treatments with zooplanktivorous fingerlings, but this was not observed in the experiment.

Therefore, we can argue that the positive effect of $O$. niloticus on phytoplankton growth was intensified in nutrient enriched treatments. The strength of trophic cascade was higher in these treatments with higher algal carrying capacity, where phytoplankton had more nutrients available and therefore reached higher biomass when released from zooplankton grazing pressure. Besides, we can additionally argue that nutrients and fish do not act as independent regulators of planktonic communities; they have effects that often can only be predicted by understanding their combined effects (Lancaster \& Drenner, 1990; Faafeng et al., 1990).

The above results seem extremely important and useful to support actions and public policies for reservoir water quality management in the Northeast of Brazil, where the Nile tilapia has been continuously introduced and became invasive. Panosso et al. (2007) have suggested that the Nile tilapia could be used in biomanipulation programs to reduce phytoplankton biomass, thus helping to maintain water quality on semiarid reservoirs. However, there are important factors to be evaluated before such programs are implemented and the overall effects of tilapia fisheries on phytoplankton biomass and water quality are to the best of our knowledge highly uncertain (Attayde \& Menezes, 2008; Menezes et al., 2010). Therefore, we believe that the management of such water resources should rely on the balance between aquaculture activities and the maintenance of the water quality for human and animal consumption. 


\section{Acknowledgements}

This work was made possible by the IC granted to Leonardo Henrique Teixeira Pinto by the Brazilian Council for Scientific Research (CNPq). The authors thank the working team of Aquatic Ecology Laboratory (LEA-UFRN), specially the colleagues Jurandir Junior, Francisco Rivera de Vasconcelos and Pablo Rubim for their collaboration to the experiment execution. We also thank the Escola Agrícola de Jundiaí - RN (EAJ - UFRN) which allowed the development of this work at their dependencies and Rosemberg Menezes for your valuable contributions to this manuscript revision.

\section{References}

AMERICAN PUBLIC HEALTH ASSOCIATION APHA. Standard methods for the examination of water and wastewater. 17th ed. Washington, 1997.

ATTAYDE, J.L. and HANSSON, L.A. Effects of nutrient recycling by zooplankton and fish on phytoplankton communities. Oecologia, 1999, 121(1), 47-54. http:// dx.doi.org/10.1007/s004420050906.

ATTAYDE, J.L. and MENEZES, R.F. Effects of fish biomass and planktivore type on plankton communities. Journal of Plankton Research, 2008, 30(8), 885-892. http://dx.doi.org/10.1093/plankt/ fbn051.

ATTAYDE, J.L., VAN NES, E.H., ARAUJO, A.I.L., CORSO, G. and SCHEFFER, M. Omnivory by planktivores stabilizes plankton dynamics, but may either promote or reduce algal biomass. Ecosystems, 2010, 13(3), 410-420. http://dx.doi.org/10.1007/ s10021-010-9327-4.

BEVERIDGE, M.C. M. and BAIRD, D.J. Diet, feeding and digestive physiology. In M.C.M. BEVERIDGE and B.J. MCANDREW, eds. Tilapias: biology and exploitation. Dordrecht: Kluwer, 2000, pp. 59-87. http://dx.doi.org/10.1007/978-94-011-4008-9_3.

CHUMCHAL, M.M. and DRENNER, R.W. Interrelationships between phosphorus loading and commom carp in the regulation of phytoplankton biomass. Archiv fuer Hydrobiologie, 2004, 161(2), 147-158. http://dx.doi.org/10.1127/00039136/2004/0161-0147.

DRENNER, R.W., GALLO, K.L., BACA, R.M. and SMITH, J.D. Synergistic effects of nutrient loading and omnivorous fish on phytoplankton biomass. Canadian Journal of Fisheries and Aquatic Sciences, 1998, 55(9), 2087-2096. http://dx.doi.org/10.1139/ f98-095.
DRENNER, R.W., SMITH, J.D. and THRELKELD, S.T. Lake trophic state and the limnological effects of omnivorous fish. Hydrobiologia, 1996, 319(3), 213-223. http://dx.doi.org/10.1007/BF00013734.

FAAFENG, B.A., HESSEN, D.O., BRABRAND, Å. and NIELSSEN, J.P. Biomanipulation and foodweb dynamics - the importance of seasonal stability. Hydrobiologia, 1990, 200/201(1), 119-128. http:// dx.doi.org/10.1007/BF02530333.

JESPERSEN, A.M. and CHRISTOFFERSEN, K. Measurements of chlorophyll- $a$ from phytoplankton using ethanol as extraction solvent. Archiv fuer Hydrobiologie, 1987, 109, 445-454.

LANCASTER, H.F. and DRENNER, R.W. Experimental mesocosm study of the separate and interactions effects of phosphorus and mosquito fish (Gambusia affinis) on plankton community structure. Canadian Journal of Fisheries and Aquatic Sciences, 1990, 47(3), 471-479. http://dx.doi. org/10.1139/f90-051.

MENEZES, R.F., ATTAYDE, J.L. and VASCONCELOS, F.R. Effects of omnivorous filter-feeding fish and nutrient enrichment on the plankton community and water transparency of a tropical reservoir. Freshwater Biology, 2010, 55(4), 767-779. http://dx.doi. org/10.1111/j.1365-2427.2009.02319.x.

OKUN, N., BRASIL, J., ATTAYDE, J. L. and COSTA, I.A.S. Omnivory does not prevent trophic cascades in pelagic food webs. Freshwater Biology, 2007, 53, 129-138.

PANOSSO, R.F., COSTA, I.A.S., SOUZA, N.R., ATTAYDE, J.L., CUNHA, S.R.S. and GOMES, F.C.F. Cianobactérias e cianotoxinas em reservatórios do estado do Rio Grande do Norte e o potencial controle das floraçóes pela tilápia do Nilo (Oreochromis niloticus). Oecologia Brasiliensis, 2007, 11(3), 433-449. http://dx.doi.org/10.4257/ oеco.2007.1103.12.

STICH, H.B. and BRINKER, A. Less is better: uncorrected versus phaeopigment-corrected photometric chlorophyll-a estimation. ArchivfürHydrobiologie, 2005, 162(1), 111-120.

VALDERRAMA, J.C. The simultaneous analysis of total nitrogen and total phosphorus in natural waters. Marine Chemistry, 1981, 10(2), 109-122. http:// dx.doi.org/10.1016/0304-4203(81)90027-X.

ZUUR, A.F., IENO, E.N. and ELPHICK, C.S. A protocol for data exploration to avoid common statistical problems. Methods in Ecology and Evolution, 2010, 1(1), 3-14. http://dx.doi.org/10.1111/j.2041210X.2009.00001.x.

Received: 20 August 2013 Accepted: 17 April 2015 